Dunamis: Jurnal Teologi dan Pendidikan Kristiani

Volume 6, Nomor 1 (Oktober 2021)

ISSN 2541-3937 (print), 2541-3945 (online)

http://www.sttintheos.ac.id/e-journal/index.php/dunamis

DOI: 10.30648/dun.v6i1.416

Submitted: 26 Agustus 2020

Accepted: 28 Januari 2021

Published: 3 Agustus 2021

\title{
Metafora Homemaking dalam Pendidikan Kristiani Keluarga pada Masa Pandemi Covid-19
}

\author{
Sri Rejeki Ulina Kaban \\ Sekolah Tinggi Filsafat Theologi Jakarta \\ srirejekiulinakaban@gmail.com
}

\begin{abstract}
This article aimed to analyze the homemaking metaphor proposed by Elizabeth Caldwell as an approach for Christian education in the family in the midst of covid-19 pandemic. By using qualitative research method, author described the challenges and strengths in conducting Christian education in the family. Furthermore, author analyzed the principles in the homemaking approach to find dimensions that provide space for process of learning together in the family. This research confirmed that the process of communal theological reflection in the homemaking approach can provide the way to find the meaning of God's Word for every family member in daily living, especially during covid-19 pandemic.
\end{abstract}

Keywords: Christian education in family; covid-19 pandemic; homemaking metaphor; theological reflection; vulnerability

\begin{abstract}
Abstrak
Artikel ini bertujuan untuk menganalisis metafora homemaking yang dikemukakan Elizabeth Caldwell sebagai pendekatan yang relevan bagi Pendidikan Kristiani dalam keluarga di tengah pandemi covid-19. Dengan metode penelitian kualitatif, penulis mendeskripsikan tantangan dan kekuatan dalam melakukan Pendidikan Kristiani di tengah keluarga. Selanjutnya, penulis menganalisis prinsip-prinsip dalam pendekatan homemaking untuk menemukan dimensi yang memberi ruang bagi proses belajar bersama di tengah keluarga. Penelitian ini menunjukkan bahwa proses berefleksi teologi bersama yang diusung oleh Caldwell dalam pendekatan homemaking dapat menjawab kebutuhan setiap anggota keluarga untuk menemukan makna Firman Tuhan bagi dirinya sendiri sehingga dapat menerapkannya dalam kehidupan sehari-hari, khususnya dalam menghadapi pandemi covid-19.
\end{abstract}

Kata Kunci: Pendidikan Kristiani dalam keluarga; pandemi covid-19; metafora homemaking; refleksi teologis; kerapuhan 


\section{PENDAHULUAN}

Pada 11 Maret 2020, Organisasi Kesehatan Dunia (World Health Organization/ WHO), sebagaimana dicatat oleh Domenico Cucinotta dan Maurizio Vanelli, telah menyatakan Corona Virus Disease 2019 (COVID-19) sebagai pandemi global. ${ }^{1}$ Pernyataan tersebut diikuti dengan peringatan untuk melakukan isolasi mandiri dan menjaga jarak (social distancing) sebagai upaya untuk memperlambat tingkat penyebaran virus tersebut. Pernyataan dan peringatan WHO tersebut menjadi pertimbangan bagi pemimpin negara-negara di dunia untuk menentukan kebijakan menghadapi pendemi covid-19. Menyikapi penyebaran covid19 di Indonesia, Presiden Joko Widodo juga menetapkan covid-19 sebagai bencana nonalam berskala nasional melalui Keputusan Presiden No. 12 tahun 2020. ${ }^{2}$ Salah satu strategi untuk mencegah penyebaran virus ini adalah menetapkan Pembatasan Sosial Berskala Besar (PSBB) pada wilayah dengan jumlah kasus covid-19 yang tinggi. Pembatasan tersebut meliputi kegiatan di sekolah, tempat kerja, tempat ibadah, dan

\footnotetext{
${ }^{1}$ Domenico Cucinotta and Maurizio Vanelli, "WHO Declares COVID-19 a Pandemic," Acta Bio Medica: Atenei Parmensis 91, no. 1 (2020): 157-160, accessed July 9, 2021, /pmc/articles/PMC7569573/. ${ }^{2}$ Kompas.com, "Presiden Jokowi Teken Keppres Tetapkan Wabah Covid-19 Bencana Nasional," https://nasional.kompas.com/read/2020/04/13/1810 1841/presiden-jokowi-teken-keppres-tetapkan-waba h-covid-19-bencana-nasional (diakses 4 November 2020).
}

fasilitas umum lainnya. ${ }^{3}$ Meskipun PSBB tidak diberlakukan di semua wilayah Indonesia, namun anjuran untuk bekerja, belajar dan beribadah di rumah tetap disampaikan kepada seluruh masyarakat Indonesia.

Menyikapi situasi tersebut, gereja ikut menyiapkan berbagai bentuk pelayanan yang baru bagi anggota jemaat, khususnya dalam melakukan ibadah. Perkembangan teknologi informasi digital yang cukup pesat ternyata sangat bermanfaat untuk menyediakan bentuk-bentuk pelayanan yang mengatasi keterbatasan ruang gerak pada masa pandemi ini, misalnya ibadah dalam jaringan (daring). ${ }^{4}$ Namun, di balik manfaat yang didapat dari teknologi informasi yang mendukung lahirnya kreativitas untuk pelayanan daring, penulis melihat pergumulan lain, yaitu tentang respons anggota jemaat dalam melakukan ibadah di rumah. Melakukan ibadah di rumah bukan sesuatu yang mudah meskipun berbagai bentuk pelayanan ibadah telah dipersiapkan oleh para pendeta untuk membantu keluarga-keluarga beribadah di rumah. Bagi yang tidak terbiasa, beribadah di rumah akan membuatnya

\footnotetext{
${ }^{3}$ Kementerian Koordinator Bidang Pembangunan Manusia dan Kebudayaan Republik Indonesia, "Pembatasan Sosial Berskala Besar," https://www. kemenkopmk.go.id/pembatasan-sosial-berskala-bes ar (diakses 4 November 2020)

${ }^{4}$ Fransiskus Irwan Widjaja et al., "Menstimulasi Praktik Gereja Rumah Di Tengah Pandemi Covid19," KURIOS (Jurnal Teologi dan Pendidikan Agama Kristen) 6, no. 1 (April 30, 2020): 127-139, accessed July 9, 2021, https://www.sttpb.ac.id/ejournal/index.php/kurios/article/view/166.
} 
merasa canggung. Selain faktor kebiasaan, pemahaman yang sempit tentang makna gereja sebagai sebuah tempat, juga dapat memengaruhi seseorang dalam melakukan ibadah di rumah.

Tantangan dalam melakukan ibadah sebagai bentuk Pendidikan Kristiani dalam keluarga di masa pandemi ini adalah: bagaimana menolong setiap anggota keluarga untuk mengomunikasikan imannya. Sebuah keluarga terdiri dari anggota dengan kategori usia yang berbeda dan setiap orang memiliki watak pertumbuhan iman yang berbeda satu sama lain. ${ }^{5}$ Sebelum masa pandemi covid-19, masing-masing anggota keluarga mendapatkan ruang untuk belajar tentang Firman Tuhan berdasarkan kategori usia yang ada di gereja, misalnya pelayanan untuk anak, pemuda, orang dewasa, dan sebagainya. Namun, pada masa pandemi ini, pengajaran Firman Tuhan berpusat di keluarga yang terdiri dari anggota keluarga dari berbagai kategori usia (intergenerasi). Dengan demikian, tantangan yang dihadapi orang tua yang berperan sebagai pendidik di tengah keluarga adalah mengupayakan agar setiap anggota keluarga dapat memaknai Firman Tuhan berdasarkan pemahamannya masing-masing.

\footnotetext{
${ }^{5}$ Keberagaman watak pertumbuhan iman digambarkan dengan metafora "taman" oleh Joas Adiprasetya untuk mengkritik model pertumbuhan iman model tangga yang bersifat homogen dan normatif. Lih. Joas Adiprasetya, "Dari Tangga Ke Taman: Multiplisitas Pertumbuhan Iman Dan Implikasinya
}

Artikel ini bertujuan untuk menganalisis metafora homemaking yang dikemukakan Elizabeth Caldwell sebagai pendekatan yang relevan bagi Pendidikan Kristiani dalam keluarga di tengah pandemi covid19. Menurut penulis, proses berefleksi teologi bersama yang diusung oleh Caldwell dalam pendekatan ini dapat menjawab kebutuhan setiap anggota keluarga untuk menemukan makna Firman Tuhan bagi dirinya sendiri sehingga dapat mengomunikasikannya dalam kehidupan sehari-hari, khususnya dalam menghadapi pandemi covid-19.

\section{METODE PENELITIAN}

Metode penelitian ini adalah kualitatif dengan studi literatur. Pertama, penulis memaparkan pentingnya peran keluarga sebagai pusat pertumbuhan iman, khususnya pada masa pandemi COVID-19. Kedua, penulis mendeskripsikan prinsip-prinsip pendekatan homemaking yang dikemukakan Elizabeth Caldwell. Selanjutnya, penulis menganalisis pendekatan homemaking untuk melihat relevansinya bagi Pendidikan Kristiani dalam keluarga pada masa pendemi COVID-19.

Bagi Karya Pedagogis, Pastoral, Dan Liturgis Gereja," DUNAMIS: Jurnal Teologi dan Pendidikan Kristiani 4, no. 2 (March 9, 2020): 127-142, accessed July 9, 2021, https://sttintheos.ac.id/ejournal/index.php/dunamis/article/view/232. 
HASIL DAN PEMBAHASAN

\section{Peran Penting Keluarga Sebagai Pusat \\ Pertumbuhan Iman di Masa Pandemi COVID-19}

Ivy Beckwith dalam bukunya berjudul Postmodern Children's Ministry menunjukkan posisi keluarga sebagai pusat pertumbuhan spiritualitas anggota keluarga. Ia menyebutkan:

The home is a place where community spiritual practices can be honed and reflected in the nurturing environment of the family. It is a place where faith can become our own in the whirl and storm of everyday life, a small, important microcosm of the larger community faith. ${ }^{6}$

Pernyataan di atas menegaskan bahwa rumah adalah tempat di mana seseorang dapat mewujudkan imannya dalam kehidupan sehari-hari, termasuk dalam menghadapi pergumulan-pergumulan hidup. Iris. V. Cully, dalam bukunya berjudul Education for Spiritual Growth, mengemukakan bahwa spiritualitas menjadi hal yang sangat penting dalam konteks masyarakat yang hidup di tengah berbagai tekanan persoalan kehidupan. Menurutnya, spiritualitas terbentuk dalam sebuah proses yang di dalamnya terda-

${ }^{6}$ Ivy Beckwith, Postmodern Children's Ministry: Ministry to Children's in the 21st Century (Grand Rapids: Zondervan, 2004), 109.

${ }^{7}$ Iris V. Cully, Education for Spiritual Growth (San Francisco: Harper \& Row, 1984), ix. pat pemeliharaan dan pendidikan yang terjadi secara terus menerus. ${ }^{7}$

Berdasarkan pandangan di atas, dapat ditegaskan bahwa dalam menghadapi pergumulan akibat pandemi covid-19, setiap orang juga dapat mengalami proses pendidikan bagi pertumbuhan spiritualitas-nya masing-masing. Namun, proses tersebut tidak terjadi begitu saja. Sebagaimana dikutip oleh Hee Ja Kim, Allen Moore mendefinisikan Pendidikan Kristiani sebagai sebuah proses belajar dan mengajar yang terjadi secara disengaja (intentional) untuk mengomunikasikan iman dalam praktik kehidupan sehari-hari. ${ }^{8}$

Ibadah adalah salah satu bentuk pengajaran iman (Pendidikan Kristiani) bagi seluruh anggota keluarga. ${ }^{9}$ Charles R. Foster menyatakan, salah satu masalah pendidikan di gereja adalah makna pengajaran Alkitab yang tidak relevan dengan konteks kehidupan masa kini. ${ }^{10}$ Hal ini juga dapat menjadi masalah pendidikan dalam keluarga sebagai komunitas iman yang juga disebut gereja. Alkitab sebagai sebuah kitab yang ditulis pada konteks tertentu pada masa lalu perlu dibaca ulang dengan perspektif konteks masa kini sehingga menjadi relevan

\footnotetext{
${ }^{8}$ Hee ja Kim, "The Nature of Christian Education," in Exploring Christian Education (Chuncheongnamdo: Hagyo Press, 2007), 17.

${ }^{9}$ Ibid, 24.

${ }^{10}$ Charles R. Foster, Educating Congregations: The Future of Christian Education (Nashville: Abingdon Press, 1994), 22.
} 
untuk menjawab pergumulan manusia saat ini. ${ }^{11}$ Tidak hanya orang dewasa, tetapi anak-anak juga perlu mendapatkan makna Firman Tuhan sesuai dengan konteks kehidupannya sehingga Firman Tuhan menjadi dasar dalam pertumbuhan spiritualitas hidup sehari-hari.

Foster menyatakan, orang-orang muda adalah kelompok yang rentan dalam kehilangan makna Firman Tuhan sesuai dengan konteks kehidupannya. ${ }^{12}$ Jika orang muda tidak menemukan relevansi Firman Tuhan yang disampaikan dengan kehidupannya, maka hal tersebut dapat menyebabkan orang-orang muda merasa kurang tertarik untuk mengikuti ibadah-ibadah di gereja yang berorientasi pada orang dewasa. Orientasi pengajaran Firman Tuhan yang mengarah pada pemahaman orang dewasa dalam ibadah-ibadah di gereja sebelum masa pandemi ini juga dapat terbawa dalam ibadah yang dilakukan dalam keluarga. Untuk itu, orang tua sebagai sosok pendidik dalam keluarga harus berjuang untuk mengomunikasikan pesan Firman Allah dalam Alkitab agar dapat dipahami oleh seluruh anggota keluarga.

Pandemi covid-19 telah menimbulkan pergumulan bagi orang tua, antara lain tentang keuangan, beban pekerjaan, keseha-

\footnotetext{
${ }^{11}$ Ibid, 24-25.

${ }^{12}$ Ibid, 25.

${ }^{13}$ Metafora anak sebagai kertas kosong atau seperti spons menunjukkan paradigma bahwa orang tua
}

tan, dan sebagainya. Di antara berbagai pergumulan tersebut, orang tua juga harus memperhatikan anak-anaknya, tidak hanya kebutuhan jasmani, tetapi juga spiritualitasnya. Pandemi ini tidak hanya berat bagi orang dewasa, tetapi situasi akibat pandemi ini juga berat bagi anak-anak. Keterbatasan ruang gerak membuat anak-anak kehilangan suasana belajar, bermain dan bersosialisasi dengan teman-teman. Meskipun terlihat santai, tetapi belajar di rumah adalah suatu aktivitas yang cukup melelahkan.

Kelelahan juga dapat dialami oleh orang tua. Orang tua harus mendampingi anak-anaknya dalam belajar sehingga mengalami kelelahan yang dapat memicu kemarahan. Konteks tersebut memperlihatkan betapa rapuhnya orang tua sebagai sosok pendidik dalam keluarga. Alih-alih memikirkan pengajaran iman bagi anak-anaknya, orang tua sendiri membutuhkan penguatan iman dalam menghadapi kesulitan dalam hidupnya.

Tanggung jawab sebagai pendidik dapat menambah tekanan bagi orang tua apalagi jika orang tua memahami bahwa anak adalah satu-satunya pihak yang belajar dan diibaratkan seperti kertas kosong ( $t a b u$ la rasa). ${ }^{13}$ Efek dari pemahaman tersebut adalah orang tua menempatkan diri sebagai

bertanggung jawab untuk membentuk anak sesuai dengan desain yang telah ditentukan orang tua sebelumnya. Lih. David M. Csinos, "Four Ways of Knowing God: Exploring Children's Spiritual 
sosok yang serba tahu dan tidak pernah salah. Hal tersebut terjadi karena pengetahuan secara kognitif dan pengalaman anakanak dianggap lebih sedikit dibandingkan dengan orang tua. Sebagaimana dikutip oleh Marcia J. Bunge, seorang teolog Jerman bernama Friedrich Schleiermacher menegaskan bahwa orang dewasa dapat belajar dari anak-anak, khususnya tentang spiritualitas hidup, di antaranya menjalani hidup sepenuhnya di saat ini (living fully in the present) dan mengampuni orang lain. ${ }^{14}$ Selain itu, bagi Yohanes Calvin, menyadari dan mensyukuri kehadiran anak-anak sebagai anugerah akan membawa kita terus berjuang untuk melewati masa-masa sulit. ${ }^{15}$

Maka, sebagai pendidik, orang tua perlu membuka diri untuk mengalami proses belajar bersama dengan anak-anak. Keberanian untuk membuka diri sebagai pribadi yang rapuh dan perlu terus belajar justru adalah sebuah kekuatan dalam mengajar sebagaimana didefinisikan oleh Parker Palmer: to teach is to create a space in which obedience to truth is practiced. ${ }^{16}$ Prinsip utama Palmer adalah bahwa pendi-

Styles," Journal of Childhood and Religion 1, no. 8 (2010): 4.

${ }^{14}$ Marcia J. Bunge, "Biblical and Theological Perspectives and Best Pratices for Faith Formation," in Understanding Children's Spirituality: Theology, Research, and Practice, ed. Kevin E. Lawson (Eugene: Cascade Books, 2012), 12.

${ }^{15}$ Ibid, 10.

${ }^{16}$ Parker J. Palmer, To Know as We Are Known: Education as a Spiritual Journey (New York: HarperCollins, 1993), 69. dikan harus berakar pada kasih yang ditandai dengan kerendahan hati dan keterbukaan terhadap kebenaran dan orang lain. ${ }^{17}$

\section{Homemaking: Sebuah Proses Refleksi}

\section{Teologi Bersama}

Pada buku Teaching the Way of Jesus, Jack L. Seymour menyebutkan bahwa kesulitan hidup dapat membuat seseorang marah, namun kemarahan itu mendorongnya untuk berdoa. ${ }^{18}$ Seymour menjelaskan bahwa dalam menghadapi kesulitankesulitan hidup, seseorang justru akan mempertanyakan secara mendalam tentang iman. Kerinduan akan sebuah perubahan menjadi pendorong untuk melakukan refleksi teologi. ${ }^{19}$ Pemahaman umum yang ada mungkin menganggap bahwa refleksi teologi hanya dapat dilakukan oleh mereka yang mendapatkan pendidikan teologi secara akademis. Seymour memahami bahwa teologi tidak sebatas sebuah bidang ilmu dalam dunia akademis, melainkan sebuah hikmat (wisdom) yang dengannya iman seseorang dikomunikasikan dalam mengha-dapi setiap situasi hidupnya. ${ }^{20}$ Refleksi teologi

\footnotetext{
${ }^{17}$ Gary A. Parrett and S. Steve Kang, Teaching the Faith, Forming the Faithful (Illinois: IVP Academic, 2009), 268.

${ }^{18}$ Jack L. Seymour, Teaching the Way of Jesus: Educating Christians for Faithful Living (Nashville: Abingdon Press, 2014), 51.

${ }^{19}$ Ibid, 51-53.

${ }^{20}$ Ibid, 94.
} 
adalah sesuatu yang penting dalam kehidupan setiap orang percaya untuk meneguhkan identitasnya sebagai anak-anak Allah dan murid Yesus. ${ }^{21}$ Namun, di sisi lain, refleksi teologis yang dilakukan berdasarkan pengalaman pribadi dapat terjebak pada pengajaran yang tidak berdasar pada Alkitab. Oleh sebab itu, Kevin J. Vanhoozer dalam bukunya berjudul “Apakah Ada Makna dalam Teks ini?" menegaskan pentingnya menjaga kejernihan makna yang dihasilkan dari pembacaan Alkitab. ${ }^{22}$ Menurutnya, pengalaman kehidupan di dunia harus dipandang dalam terang Firman daripada mencoba untuk memaksakan Firman Tuhan ke dalam wawasan dunia sekuler yang sering kali tidak cocok. ${ }^{23}$

Meskipun Seymour menyatakan semua orang dapat melakukan refleksi teologis, namun Seymour tetap menegaskan pentingnya berpijak pada tradisi iman sebagai dasar untuk merefleksikan iman dalam realitas kehidupan saat ini dan berjuang untuk hidup setia dalam imannya. $^{24}$ Menurut Seymour, pendekatan instruksi adalah pendekatan yang mendorong gereja untuk ber-

\footnotetext{
${ }^{21}$ Ibid, 55.

${ }^{22}$ Kevin J. Vanhoozer, Apakah Ada Makna Dalam Teks Ini?, trans. Jadi S. Lima (Surabaya: Momentum, 2008), 610.

${ }^{23}$ Ibid, 611.

${ }^{24}$ Seymour, Teaching the Way of Jesus: Educating Christians for Faithful Living, 95.

${ }^{25}$ Ibid, 94.

${ }^{26}$ Ibid, 90.
}

pikir secara teologis. ${ }^{25}$ Pandangan ini didasarkannya pada pola pengajaran Yesus. Yesus mengajar melalui tindakan, seperti menyembuhkan, mengusir setan, dan memberi makan orang banyak. Yesus juga mengajar melalui peribahasa dan perumpamaan. Pola pengajaran tersebut mengajak orang banyak untuk menyadari realitas kehidupan, mendapatkan pemahaman, dan mengundang untuk melakukan perubahan berdasarkan pemahaman akan kehadiran dan anugerah Allah. ${ }^{26}$

Homemaking adalah sebuah metafora yang dipakai oleh Elizabeth Caldwell untuk menjelaskan pendekatan instruksi religius (religious instruction). ${ }^{27}$ Istilah instruksi pada umumnya dipahami sebagai perintah atau arahan yang bersifat satu arah sehingga dapat menimbulkan kesalahpahaman tentang pendekatan instruksi religius ini. Kesalahpahaman tentang pendekatan instruksi religius juga disadari oleh Sara P. Little sehingga pada tulisannya berjudul Religius Instruction, Little menjelaskan pengertian dan karakteristik dari pendekatan tersebut. Instruksi kerap dipahami sebagai

\footnotetext{
${ }^{27}$ Selain Elizabeth Caldwell, beberapa tokoh Pendidikan Kristiani lainnya juga membahas tentang istilah homemaking, di antaranya Mary Catherine Bateson, Sharon Daloz Parks, Sara Little, Letty Russell, dan Nelle Morton. Lihat Elizabeth Caldwell, "Religious Instruction: Homemaking," in Mapping Christian Education: Approaches to Congregational Learning, ed. Jack L. Seymour (Nashville: Abingdon Press, 1997).
} 
pendekatan yang bersifat administratif dan formal. ${ }^{28}$ Selain itu, istilah instruksi juga dipahami sebagai suatu perintah atau pendapat yang disampaikan oleh guru dan harus diterima oleh naradidik. ${ }^{29}$ Little menolak pemahaman tersebut dengan memberi pengertian instruksi religius sebagai sebuah proses menggali tradisi gereja dan pemahaman diri di mana setiap orang dapat memahami, menilai, dan merespon kebenaran Firman Tuhan. ${ }^{30}$ Untuk itu, Little menyebutkan tiga karakteristik dalam pendekatan tersebut, yaitu memahami (understanding), memutuskan (deciding), dan percaya (believing). Melalui karakteristik tersebut, Little menggarisbawahi bahwa hal yang penting dalam pendekatan ini adalah berpartisipasi secara sadar. ${ }^{31}$ Dengan kesadaran tersebut, pendekatan instruksi religius dapat menolong setiap orang untuk percaya berdasarkan kebenaran yang telah dipahaminya. ${ }^{32}$

Sebagaimana Little dan Seymour menjelaskan instruksi religius sebagai pendekatan yang mengundang partisipasi secara aktif dalam memahami Firman Tuhan, demikian pula Caldwell menggambarkan keterbukaan pendekatan ini dengan metafo-

\footnotetext{
${ }^{28}$ Sara P. Little, "Religious Instruction," in Contemporary Approaches Christian Education, ed. Jack L. Seymour and Donald E. Miller (Nashville: Abingdon Press, 1982), 36.

${ }^{29}$ Ibid.

${ }^{30}$ Ibid.

${ }^{31}$ Ibid, 44.

${ }^{32}$ Ibid, 47.
}

ra homemaking. Dengan menggunakan metafora homemaking, Caldwell menjelaskan pendekatan instruksi religius sebagai sebuah pendekatan yang terbuka bagi setiap anggota dalam komunitas iman selayaknya merasakan kenyamanan dalam rumah sendiri. ${ }^{33}$ Caldwell menggunakan metafora homemaking untuk mengingatkan bahwa di dalam gereja seharusnya tidak ada sekat antara anggota yang berbeda usia. Caldwell menekankan pentingnya membangun "rumah" untuk belajar dan bertumbuh bersama sebagai sebuah komunitas iman. ${ }^{34}$ Caldwell membandingkan sikap seseorang ketika berada di rumah orang asing dan di rumah sendiri. Ketika berada di rumah orang asing, seseorang akan merasa kurang nyaman. Namun, ketika berada di rumah sendiri seseorang akan merasa lebih nyaman dan menjadi dirinya sendiri. ${ }^{35}$ Demikianlah metafora homemaking menggambarkan suasana lingkungan belajar yang nyaman bagi setiap orang untuk menjadi dirinya sendiri. Homemaking merupakan sebuah proses refleksi teologi bersama yang memberi ruang bagi pertumbuhan iman setiap anggota sebagai sebuah keluarga. ${ }^{36}$

\footnotetext{
${ }^{33}$ Caldwell, "Religious Instruction: Homemaking," 78

${ }^{34}$ Ibid.

${ }^{35}$ Seymour, Teaching the Way of Jesus: Educating Christians for Faithful Living, 91.

${ }^{36}$ Caldwell, "Religious Instruction: Homemaking," 81.
} 
Pada konteks pandemi covid-19 saat ini, setiap orang dianjurkan untuk tetap tinggal di rumah. Artinya, setiap orang lebih banyak menghabiskan waktu di rumah bersama anggota keluarganya. Situasi ini menegaskan bahwa rumah bukan sekadar sebuah tempat, tetapi rumah adalah tentang kehidupan, termasuk tentang pertumbuhan iman. ${ }^{37}$ Kesadaran bahwa rumah menjadi pusat pertumbuhan iman semakin meningkat di masa pandemi covid-19, ketika pemerintah menganjurkan untuk melakukan ibadah di rumah. Berdasarkan konteks ini, metafora homemaking memberikan peluang untuk membangun "rumah" bagi pertumbuhan iman seluruh anggota keluarga sebab setiap orang diundang untuk berpartisipasi dalam dialog dan refleksi bersama tentang Firman Tuhan.

Caldwell mendaftarkan tujuan dari pendekatan homemaking berdasarkan prinsip-prinsip instruksi religius, yaitu pertama, memungkinkan naradidik untuk memiliki dasar iman Alkitabiah. ${ }^{38}$ Meskipun pendekatan homemaking memberi ruang partisipasi bagi naradidik untuk melakukan refleksi atas Firman Tuhan, namun Caldwell me-

\footnotetext{
${ }^{37}$ Djeffry Hidajat mencatat, dalam konteks Perjanjian Baru, rumah tidak hanya berfungsi sebagai tempat tinggal, melainkan memiliki fungsi lainnya, yaitu fungsi ekonomi, sosial dan religius. Lih. Djeffry Hidajat, "Gereja Di Rumah: Kontekstualisasi Fungsi-Fungsi Rumah Dalam Masa Perjanjian Baru Untuk Pekabaran Injil," Veritas: Jurnal Teologi dan Pelayanan 17, no. 2 (December 1, 2018): 107-117, accessed July 9, 2021,
}

negaskan bahwa pendekatan ini tetap mengedepankan pentingnya dasar-dasar iman Alkitabiah sebagai panduan dalam melakukan refleksi. ${ }^{39}$ Dengan memahami dasar-dasar iman Alkitabiah, naradidik ditolong untuk mewujudnyatakan iman dalam kehidupan sehari-hari. ${ }^{40}$ Kedua, menciptakan ruang yang terbuka terhadap semua tipe belajar naradidik dan membangun refleksi dan dialog. ${ }^{41}$ Karen B. Tye menyatakan bahwa masalah besar dalam pengajaran iman adalah pemahaman bahwa setiap orang belajar dengan cara yang sama, sedangkan sesungguhnya setiap orang memiliki tipe belajar yang unik dalam menerima dan memproses data dan pengalaman untuk menemukan makna dari data dan pengalaman tersebut. ${ }^{42}$ Tye mencatat tujuh tipe belajar yang dikemukakan oleh Wayne James dan Michael Galbraith, yaitu: visual (belajar dengan mengobservasi benda atau sesuatu yang dapat dilihat seperti gambar, grafik, atau tabel); print (belajar dengan membaca tulisan); aural (belajar dengan mendengar); interactive (belajar dengan berbicara secara interaktif seperti dalam diskusi); haptic (belajar dengan merasakan, menyentuh, dan

\footnotetext{
https://ojs.seabs.ac.id/index.php/Veritas/article/vie $w / 310$.

${ }^{38}$ Caldwell, "Religious Instruction: Homemaking," 79.

${ }^{39}$ Ibid.

${ }^{40}$ Ibid.

${ }^{41}$ Ibid, 79-80.

${ }^{42}$ Karen B. Tye, Basics of Christian Eduaction (USA: Chalice Press, 2000), 82.
} 
memegang sesuatu); olfactory (belajar dengan menggunakan indra penciuman dan perasa), dan kinesthetic (belajar dengan menggerakkan anggota badan). ${ }^{43}$ Masing-masing individu dapat memiliki lebih dari satu tipe belajar yang dominan pada dirinya. ${ }^{44}$ Berbagai tipe belajar tersebut menjadi sebuah pertimbangan penting dalam proses pengajaran iman dan pendekatan homemaking memberi ruang untuk keberagaman tipe belajar ini melalui refleksi dan dialog atas makna yang ditemukan setiap orang. Ketiga, memperhatikan metode pengajaran yang mendorong naradidik untuk berpikir tentang isi pengajaran. ${ }^{45}$ Sebagaimana dinyatakan oleh Carol Lakey Hess, percakapan dalam pendidikan memerlukan upaya untuk melakukan dialog sebab dialog memberi ruang untuk mendengarkan, merespon, mengkritik, dan mempertanyakan. ${ }^{46}$ Demikian pentingnya dialog dalam kehidupan manusia, Reuel L. Howe menyebutkan bahwa dialog dapat menciptakan keajaiban, yaitu membuat relasi menjadi ada, bahkan dapat memunculkan kembali hubungan yang telah mati. ${ }^{47}$ Keempat, menjalin hubungan antara iman dan kehidupan seharihari. $^{48}$

\footnotetext{
${ }^{43}$ Ibid, 83-84.

${ }^{44}$ Ibid, 84.

${ }^{45}$ Caldwell, "Religious Instruction: Homemaking," 80 .

${ }^{46}$ Ibid.

${ }^{47}$ Reuel L. Howe, The Miracle of Dialogue (New York: The Seabury Press, 1963), 3.
}

Beranjak dari tujuan di atas, pendidik dalam proses belajar dengan menggunakan pendekatan instruksi ini memiliki beberapa tugas. Pertama, seorang pendidik bertanggung jawab untuk membangun ruang yang memberi nilai terhadap integritas dari isi pelajaran, naradidik dan tindakan praktis yang menjadi implikasi dari iman yang dipercakapkan. ${ }^{49}$ Kedua, pendidik perlu melihat proses belajar secara utuh. Artinya, proses belajar tidak semata-mata tentang isi pelajaran tetapi di dalamnya ada relasi yang perlu dibangun, misalnya rasa saling percaya satu dengan yang lain dalam lingkungan belajar tersebut. ${ }^{50}$ Ketiga, pendidik bertanggung jawab untuk menciptakan sebuah visi. ${ }^{51}$ Dengan kata lain, dalam pendekatan ini, pendidik mendorong naradidik untuk berpikir, berefleksi tentang Firman Tuhan sesuai dengan pengalaman mereka dan menentukan sikap hidup sebagai respons terhadap panggilan Tuhan. ${ }^{52}$

Jika ketiga tugas pendidik tersebut membuka ruang bagi partisipasi naradidik dalam proses belajar, maka anggapan bahwa naradidik ibarat kertas kosong tidaklah sah. Caldwell menyebut naradidik sebagai kontributor. ${ }^{53}$ Naradidik tidak hanya duduk

\footnotetext{
${ }^{48}$ Caldwell, "Religious Instruction: Homemaking," 80 .

${ }^{49}$ Ibid, 81 .

${ }^{50}$ Ibid, 82.

${ }^{51}$ Ibid.

${ }^{52}$ Ibid.

${ }^{53}$ Ibid, 83.
} 
dan mendengarkan dalam proses belajar. Ada dua dimensi yang menjadi perhatian dalam peran naradidik pada proses belajar ini. Dimensi yang pertama berfokus pada apa yang dibawa oleh naradidik dalam proses belajar dan tindakan yang dilakukan naradidik selama proses belajar tersebut. Dimensi yang kedua berkaitan dengan tipe lingkungan belajar seperti apa yang dibangun oleh pendidik. Jika pendidik membangun model kemitraan (partnership), maka baik pendidik maupun naradidik memiliki tanggung jawab untuk mendengarkan dan berbicara. $^{54}$

Pertanyaan yang dapat muncul ketika pendekatan homemaking ini dilakukan di dalam keluarga adalah: bagaimana anakanak dapat berpartisipasi dalam refleksi teologis? Pertanyaan tersebut dilatarbelakangi oleh pemahaman bahwa proses belajar hanya melibatkan aspek kognitif. Justitia Vox Dei Hattu dalam tulisannya berjudul "Mengajar (dan Belajar) dengan Hati: Sebuah Kritik dan Alternatif terhadap Proses Pembelajaran yang Mengutamakan Dimensi Kognitif', mengungkapkan bahwa jika mengajar hanya mengutamakan dimensi kognitif, maka yang terjadi adalah proses mentransfer ilmu. ${ }^{55}$ Belajar tidak hanya tentang

\footnotetext{
${ }^{54}$ Ibid, 83-84.

${ }^{55}$ Justitia Vox Dei Hattu, "Mengajar (Dan Belajar) Dengan Hati: Sebuah Kritik Dan Alternatif Terhadap Proses Pembelajaran Yang Mengutamakan Dimensi Kognitif," in Mendidik Dalam Kasih, Keadilan, Dan
}

meningkatkan pemahaman secara kognitif, tetapi harus melibatkan seluruh aspek dalam diri manusia. Parrett dan Kang menegaskan:

We aim at transformation of the whole person of this there can be no question. Toward that end, all aspects of our humanity must be engaged, including our ayes and ears (perception), heads (cogintion), hearts (affection), and hands and feet (behavior). ${ }^{56}$

Anak-anak memiliki rasa ingin tahu yang cukup tinggi. Hal ini tampak dalam pertanyaan-pertanyaan yang mendasar tentang kehidupan dan Tuhan, misalnya: "Tuhan tinggal di mana?", "Bagaimana aku dilahirkan?”, dan sebagainya. Pertanyaanpertanyaan tersebut adalah sebuah tanda bahwa anak-anak juga dapat terlibat dalam proses berefleksi teologis. Menurut David Heller, sebelum menjawab pertanyaan anak-anak yang cukup sulit untuk dijelaskan, orang tua terlebih dahulu perlu membangun rasa aman dan nyaman dalam kehidupan mereka. Heller menyatakan bahwa pertumbuhan spiritualitas anak adalah pertumbuhan cara pandang anak terhadap dunia. Pertumbuhan spiritualitas anak adalah sebuah proses di mana anak membangun pandangannya tentang dirinya, keluar-

Kebenaran, ed. Justitia Vox Dei Hattu (Jakarta: STFT Jakarta, 2019), 1.

${ }^{56}$ Parrett and Kang, Teaching the Faith, Forming the Faithful, 298. 
ga dan segala sesuatu yang ada dalam kehidupannya. Maka, hal utama bagi para orang tua adalah menjamin bahwa anak berada pada sebuah situasi di mana mereka merasa berharga dan dapat menghargai kehidupan. ${ }^{57}$ Rito Baring juga mencatat hasil penelitian tentang faktor yang memengaruhi pemahaman anak tentang Allah seperti penelitian de Roos' yang menyatakan bahwa pemahaman anak tentang Allah sangat dipengaruhi oleh pandangannya tentang pengasuhnya, dalam hal ini orang tua atau guru. ${ }^{58}$

Tidak dapat dipungkiri bahwa situasi kehidupan manusia tidak selalu baik. Ada saat di mana manusia merasa lemah, sedih, marah, takut, bosan, dan sebagainya. Berbagai macam perasaan tersebut memperlihatkan bahwa manusia adalah pribadi yang rapuh dan berbeda satu sama lain. Meskipun perasaan dan keadaan yang dialami tidak selalu baik, namun penerimaan terhadap semua kemungkinan keadaan tersebut adalah sebuah sikap menghargai kehidupan itu sendiri. Yesus, dalam kehidupanNya di dunia, memperlihatkan sisi kerapuhan-Nya sebagai manusia. Pada Markus 14:34 dicatat: lalu kata-Nya kepada mereka: "Hati-Ku sangat sedih, seperti mau mati rasanya. Tinggallah di sini dan berjaga-ja-

\footnotetext{
${ }^{57}$ David Heller, Talking to Your Child about God (New York: Bantam Books, 1988), 5.

${ }^{58}$ Rito Baring, "Children's Image of God and Their Parents: Explorations in Children's Spirituality," International Journal of Children's Spirituality 17,
}

galah." Ungkapan perasaan tersebut disampaikan-Nya kepada tiga orang murid-Nya, yaitu Petrus, Yakobus, dan Yohanes di sebuah tempat bernama Getsemani. Ungkapan tersebut menegaskan keberanian dan kerendahan hati seorang Guru mengakui kerapuhan-Nya di hadapan murid-muridNya. Parrett dan Kang menggarisbawahi sikap Yesus tersebut sebagai sebuah tanda kedekatan hubungan sebagai sahabat sebagaimana yang ditegaskan dalam pernyataan Yesus kepada murid-murid-Nya: "Aku tidak menyebut kamu lagi hamba, sebab hamba tidak tahu, apa yang diperbuat oleh tuannya, tetapi Aku menyebut kamu sahabat, karena Aku telah memberitahukan kepadamu segala sesuatu yang telah Kudengar dari Bapa-Ku." (Yoh. 15:15). ${ }^{59}$ Dengan meneladani Yesus sebagai Sang Guru, orang tua sebagai guru bersedia menjadi sahabat bagi anak-anaknya dalam proses belajar di tengah keluarga. Hubungan sahabat memperlihatkan keterbukaan untuk menerima orang lain secara utuh.

Norma Cook Everist, dalam bukunya The Church as Learning Community, menyatakan:

To be ignorant is to be uneducated, or at least uninformed. We as religious educators are ignorant when

no. 4 (November 1, 2012): 277-289, accessed July 9, 2021, https://www.tandfonline.com/doi/abs/10. 1080/1364436X.2012.746935.

${ }^{59}$ Parrett and Kang, Teaching the Faith, Forming the Faithful, 188-189. 
we choose to ignore the names, lives, experiences, languages, viewpoints, wisdom, or capabilities of the learners. ${ }^{60}$

Menurutnya, melupakan atau mengabaikan adalah sikap membiarkan seseorang berada di luar komunitas belajar. Sebaliknya, membuka diri untuk mengenal orang lain adalah sebuah kesediaan untuk menjadi mitra dalam proses belajar bersama orang lain. ${ }^{61}$ Orang tua mungkin tidak menyadari adanya sikap mengabaikan anak-anaknya. Berdasarkan pernyataan Everist sebelumnya, sikap mengabaikan naradidik tidak sebatas melupakan nama atau kehadiran naradidik, tetapi seorang guru dapat disebut mengabaikan naradidik ketika ia tidak mempertimbangkan pengalaman, bahasa, sudut pandang, dan kemampuan dari naradidik dalam proses belajar. Robert Coles, sebagaimana dicatat oleh David M. Csinos, melakukan percakapan dengan ratusan anak dari berbagai latar belakang agama dan menyebutkan bahwa setiap orang muda memiliki kehidupan spiritual bawaan yang bertumbuh, berubah, dan merespons situasi kehidupan secara terus menerus. ${ }^{62}$ Dengan kata lain, warisan tradisi atau pengajaran yang diberikan kepada seseorang akan berinteraksi dengan narasi-narasi kehidupan pribadinya.

\footnotetext{
${ }^{60}$ Norma Cook Everist, The Church as Learning Community: A Comprehensive Guide to Christian Education (Nashville: Abingdon Press, 2002), 38. ${ }^{61}$ Ibid.
}

Mengacu pada prinsip-prinsip pendekatan homemaking yang dikemukakan Caldwell, penulis berargumentasi, pendekatan ini relevan untuk digunakan pada proses belajar bersama dalam keluarga pada masa pandemi covid-19 ini. Orang tua membuka ruang partisipasi bagi seluruh anggota keluarga sekaligus bersedia untuk belajar dari pengalaman setiap anggota keluarga. Pada dasarnya, Caldwell tidak menetapkan secara eksplisit tentang konteks tertentu yang cocok untuk menggunakan pendekatan ini. Namun Caldwell memperlihatkan bahwa ada berbagai situasi dalam kehidupan yang dapat dipertimbangkan sebagai bentuk proses belajar, misalnya melakukan retreat, makan bersama, berbincang-bincang antara orang tua dan anak, dan sebagainya. Artinya, berbagai kegiatan sehari-hari dapat menjadi kesempatan untuk mengajar dan belajar tentang iman Kristen. ${ }^{63}$ Misalnya, setelah makan bersama, setiap anggota keluarga dapat menceritakan perasaan atau pendapatnya tentang pemeliharaan Tuhan melalui makanan dan minuman di masamasa sulit seperti pandemi covid-19.

Dengan menggunakan pendekatan homemaking, pengajaran Firman Tuhan tidak lagi sebatas rutinitas yang bergantung

\footnotetext{
${ }^{62}$ Csinos, "Four Ways of Knowing God: Exploring Children's Spiritual Styles," 6.

${ }^{63}$ Caldwell, "Religious Instruction: Homemaking," 86.
} 
pada jadwal yang ditetapkan oleh gereja. Ibadah tidak terbatas pada tempat tertentu sehingga pada masa pandemi ini setiap orang dapat beribadah meskipun tidak pergi ke gedung gereja. Ibadah menjadi sebuah proses belajar tentang Firman Tuhan yang dapat terjadi dalam setiap keadaan. Pendekatan homemaking menolong setiap orang dapat melakukan refleksi teologi atas rasa takut, rasa cemas, rasa bahagia, dan keadaan lainnya.

\section{KESIMPULAN}

Ketika pademi covid-19 mendesak semua orang untuk tetap tinggal di rumah, kebutuhan untuk merasa nyaman menjadi sesuatu yang penting untuk dipenuhi. Relasi saling menerima antara seluruh anggota keluarga adalah faktor utama dalam membangun rumah sebagai sebuah lingkungan belajar yang nyaman untuk pertumbuhan spiritualitas sekalipun dalam masa-masa sulit. Homemaking adalah sebuah pendekatan yang memberi ruang bagi setiap orang untuk menemukan makna dalam proses belajar. Pendekatan homemaking ini relevan untuk melakukan Pendidikan Kristiani di tengah-tengah keluarga, khususnya dalam pergumulan menghadapi pandemi covid-19 sebab di saat setiap orang mengalami keterbatasan ruang gerak, pendekatan ini menolong setiap anggota keluarga untuk mendapatkan ruang untuk merefleksikan pengalamannya masing-masing.

\section{DAFTAR PUSTAKA}

Adiprasetya, Joas. "Dari Tangga $\mathrm{Ke}$ Taman: Multiplisitas Pertumbuhan Iman Dan Implikasinya Bagi Karya Pedagogis, Pastoral, Dan Liturgis Gereja." DUNAMIS: Jurnal Teologi dan Pendidikan Kristiani 4, no. 2 (March 9, 2020): 127-142. Accessed July 9, 2021. https:// sttintheos.ac.id/e-journal/index.php/ dunamis/article/view/232.

Baring, Rito. "Children's Image of God and Their Parents: Explorations in Children's Spirituality." Inter national Journal of Children's Spirituality 17, no. 4 (November 1, 2012): 277-289. Accessed July 9, 2021. https://www.tandfonline.com/ doi/abs/10.1080/1364436X.2012.74 6935.

Beckwith, Ivy. Postmodern Children's Ministry: Ministry to Children's in the 21st Century. Grand Rapids: Zondervan, 2004.

Bunge, Marcia J. "Biblical and Theological Perspectives and Best Pratices for Faith Formation." In Understanding Children's Spirituality: Theology, Research, and Practice, edited by Kevin E. Lawson. Eugene: Cascade Books, 2012.

Caldwell, Elizabeth. "Religious Instruction: Homemaking." In Mapping Chris tian Education: Approaches to Congregational Learning, edited by Jack L. Seymour. Nashville: Abingdon Press, 1997.

Csinos, David M. "Four Ways of Knowing God: Exploring Children's Spiritual Styles." Journal of Childhood and Religion 1, no. 8 (2010): 4.

Cucinotta, Domenico, and Maurizio Vanelli. "WHO Declares COVID19 a Pandemic." Acta Bio Medica : Atenei Parmensis 91, no. 1 (2020): 157-160. Accessed July 9, 2021. /pmc/articles/PMC7569573/. 
Cully, Iris V. Education for Spiritual Growth. San Francisco: Harper \& Row, 1984.

Everist, Norma Cook. The Church as Learning Community: A Compre hensive Guide to Christian Educa tion. Nashville: Abingdon Press, 2002.

Foster, Charles R. Educating Congrega tions: The Future of Christian Education. Nashville: Abingdon Press, 1994.

Hattu, Justitia Vox Dei. "Mengajar (Dan Belajar) Dengan Hati: Sebuah Kritik Dan Alternatif Terhadap Proses Pembelajaran Yang Mengutamakan Dimensi Kognitif." In Mendidik Dalam Kasih, Keadilan, Dan Kebenaran, edited by Justitia Vox Dei Hattu. Jakarta: STFT Jakarta, 2019.

Heller, David. Talking to Your Child about God. New York: Bantam Books, 1988.

Hidajat, Djeffry. "Gereja Di Rumah: Kontekstualisasi Fungsi-Fungsi Rumah Dalam Masa Perjanjian Baru Untuk Pekabaran Injil." Veritas: Jurnal Teologi dan Pelayanan 17, no. 2 (December 1, 2018): 107-117. Accessed July 9, 2021. https://ojs.seabs.ac.id/index. $\mathrm{php} /$ Veritas/article/view/310.

Howe, Reuel L. The Miracle of Dialogue. New York: The Seabury Press, 1963.

Kim, Hee ja. "The Nature of Christian Education." In Exploring Christian
Education. Chuncheongnam-do: Hagyo Press, 2007.

Little, Sara P. "Religious Instruction." In Contemporary Approaches Chris tian Education, edited by Jack L. Seymour and Donald E. Miller. Nashville: Abingdon Press, 1982.

Palmer, Parker J. To Know as We Are Known: Education as a Spiritual Journey. New York: HarperCollins, 1993.

Parrett, Gary A., and S. Steve Kang. Teaching the Faith, Forming the Faithful. Illinois: IVP Academic, 2009.

Seymour, Jack L. Teaching the Way of Jesus: Educating Christians for Faithful Living. Nashville: Abingdon Press, 2014.

Tye, Karen B. Basics of Christian Eduaction. USA: Chalice Press, 2000.

Vanhoozer, Kevin J. Apakah Ada Makna Dalam Teks Ini? Translated by Jadi S. Lima. Surabaya: Momentum, 2008.

Widjaja, Fransiskus Irwan, Candra Gunawan Marisi, T. Mangiring Tua Togatorop, and Handreas Hartono. "Menstimulasi Praktik Gereja Rumah Di Tengah Pandemi Covid19." KURIOS (Jurnal Teologi dan Pendidikan Agama Kristen) 6, no. 1 (April 30, 2020): 127-139. Accessed July 9, 2021. https://www .sttpb.ac.id/ejournal/index.php/kuri os/article/view/166. 